The Japanese Journal of Experimental

Social Psychology. 1989, Vol. 29, No. 2, 141-151

〔原

著]

\title{
大学生における孤独感と対処方略1) 2)
}

\author{
静 岡大学 \\ 諸 井 克 英
}

問題

日常的に広く経験される情動の一つである孤独感につ いて, 近年, UCLA の研究グループを中心として, UCLA 孤独感尺度の開発をはじめ (Russell et al., 1980), さま ざまな研究が行われている。

UCLA の研究グループである Peplau \& Perlman （1979）は孤独感の認知的くいちがいモデルを提起し た。このモデルによれば，孤独感は社会的相互作用につ いての願望水準と達成水準とのくいちがいの認知によっ て生じる不快経験である。彼らは, このモデルとともに, 孤独に対する対処方略図式も提出した。すなわち, 人は, 孤独に陥ったときに，a）願望水準の変化，b）達成水 準の変化，c）両水準のくいちがいの重要性や知覚され たその程度の変化，という 3 つの基本的な対処方略を用 いて，その孤独状態からのがれようとする。

孤独感は，自尊心の低下，うつ傾向などのさまざまな 心理学的兆候や, 身体的兆候を伴っている (Russell et al., 1980 ; 工藤・西川，1983）。しかし，孤独からのが れるためにセラピストなどの専門的治療家の援助を求め る者が少ない (Rook \& Peplau, 1982)。したがって, 孤 独に対する対処方略の基本的構造と, 孤独感と対処方略 との関連を解明することは, 孤独感の心理学的解明のみ ならず，高孤独者に対する専門的治療の開発にとっても 有益であろう。

孤独感の対処方略の基本的構造については，さまざま な対象について因子分析的研究が行われ，4因子から 12 因子までの対処方略因子が得られている（中学生：工藤, 1986 ; 大学生: Paloutzian \& Ellison, 1982 ; 広沢, 1985，1986; Shaver et al., 1985 ; 工藤ら， 1986 ; 一般 人：Rubenstein \& Shaver, 1982 ; 工藤ら, 1986 ; 老人：
工藤ら，1984）。対象に特徵的な方略もあるが（例えば， 工藤（1986）の違法行動因子), 社会的関係の改善·活性 化, 孤独に対する無抵抗を示す消極的受容, 非対人的活 動への従事・没頭による代償的満足などが, 研究に共通 して得られている。しかし, 先行研究で使用されている 対処方略項目をみると, 対人的一非対人的反応の区別が 曖昧な表現が多くみうけられる(例えば, テレビをみ る)。また, 工藤ら (1984) の研究を除き, 男女をまとめ て対処方略の構造を検討している。孤独感の強さに性差 があることを考慮すると (Borys \& Perlman, 1985 ; 諸 井, 1985，1987）, 孤独感の対処方略の基本的構造にも性 差があると推測される。

孤独感と対処方略との関連については, 因子水準 (Rubenstein \& Shaver, 1982 ; Shaver et al., 1985 ; 工 藤ら, 1986 ; 広沢, 1986), 項目水準 (工藤, 1986), そ れぞれで, 孤独感に対する抑制的および促進的な対処方 略が見出されている。Peplauらの対処方略図式は, 孤独 感を抑制することが含意されているが，消極的な対処は むしろ孤独感を高めている。

ところで, 孤独感は, 状況に主として規定される一過 的な事態特性成分と, 状況の影響を被りにくい慢性的な 個体特性成分とから成ると考えられる。例えば, 大学入 学直後に生起する孤独感は主として前者の成分の高まり といえる (Cutrona, 1982 ; 諸井, 1986)。この 2 つの成 分を操作的に区別する試みが先行研究で行われている。 Gerson \& Perlman (1979) は，“ここ2 週間の状態”, “通常の状態”という 2 基準で孤独感尺度を評定させ, 両評定ともに高い孤独感を示す慢性的孤独者と, 前者で は高いが後者では低い孤独感を示す状況的孤独者を区別 した。Cutrona (1982) は，2 時点での孤独感の自己報告 に基づき， 2 時点ともに孤独感の高い慢性的孤独者と，

1）本論文作成にあたり，名古屋大学文学部辻敬一郎教授に貴重な御示唆を頂いた。

2 ) 本論文に扔ける調查の主要部分は, 筆者の指導の下で, 水谷直義君, 守谷洋子啐(社会学科昭和61年度卒業) が卒業論文研究のために計画・実施した。なお, 調査実施の際には, 静岡大学教養部漁田武雄助教授に御協 力を頂いた。 
最初は高いが後に低くなった一過的孤独者とに被験者を 選別した。Shaver et al. (1985) は, “ここ数日間”, “こ こ数年間”という基準で孤独感尺度を評定させ, 前者を 状態一孤独感, 後者を特性一孤独感とした。また, Beck \& Young (1978) は, 孤独感の時間的持続性に基づく概 念的区別を提唱した。それによると, 数年にわたる社会 的関係の不全に由来する慢性的孤独感, 大学入学や特定 の他者との別離などの状況的変化に伴う状況的孤独感, 他者との接触により容易に消失する一時的気分である一 過的孤独感という 3 つに孤独感は区別される。

孤独感の一過的な事態特性成分と慢性的な個体特性成 分との区別は，対処方略の有効性を検討する上で重要で あろう。従来の対処方略研究では, 孤独感と対処方略と の関係が認められても, 例えば, 一過的に有効な対処に すぎないのかどうかは恣意的な解釈に依存していた。

本研究では, 評定時に回答者が思い浮べる時間的範囲 を基準とする孤独感（Shaver et al., 1985）を，それぞ れ, 短期的孤独感, 長期的孤独感と呼ぶ。また, 2 基準 あるいは 2 時点で測定された孤独感の水準の一致・不一 致によって定義された孤独感（Gerson \& Perlman, 1979 ; Cutrona, 1982) を, それぞれ, 一過的孤独感, 慢 性的孤独感と呼ぶ。Fridhandler (1986) は, 状態と特性 という 2 概念の区別を試み，a）時間的持続性（短期対 長期), b ) 特定の環境条件に対する反応性(連続対不連 続)，c）概念化の水準(具体的対抽象的), およびd）因 果性の所在 (状況対性格), という 4 基準を提起してい る。これに従えば, 短期的一長期的孤独感の区別は $\mathrm{a})$, 一過的一慢性的孤独感の区別は a ), c )，d）に基づく といえよう。

本研究では, 孤独感の対処方略の基本的構造を明らか にし, 孤独感と対処方略との関連を検討することを, 主 な目的とする。

ところで, 過去の孤独感研究における性差を検討した Borys \& Perlman (1985) は, UCLA 孤独感尺度を用 いた場合には，一般的に女子よりも男子のほうが高い孤 独感を示すことを見出した。諸井（1985，1987）の研究 でも, 高校生や大学生で同様の性差が得られ, さらに, 孤独感と自尊心が負の関係にあるのに, 男子のほうが自 尊心も高かった。これらの傾向は, 通常用いられる“日 ごろの状態” という基準で孤独感尺度を評定させて得ら れたものであるが, 孤独感評定の時間的範囲を変えても, a）孤独感における性差およびb）男女における孤独感 と自尊心との矛盾する関係が出現するかどうかは, 興味 がある。性役割上, 情動的弱さや苦悩の表明が許容され ないために男子が孤独に陥りやすいというBorys \&
Perlman（1985）の解釈が妥当であれば，男子はとくに 慢性的孤独傾向を示し, 短期的孤独感よりも長期的孤独 感のほうが自尊心との関係が強いと考えられる。これら の点に関する検討を本研究の付加的目的とする。

なお, 以上に述べた目的のために大学生を対象とする 調査を行ったが, 2 つの基準での孤独感尺度の評定, お よび対処方略因子の妥当性の検討のために, 被験者の一 部に対して追跡調查を行った。

\section{方 法}

\section{被験者および質問紙の実施}

国立大学の教養部で “心理学”を受講している 1,2 年生を調査対象とした。質問紙は, “青年の行動・意識” 調査の名目で1986年 6 月下旬および 7 月上旬に, 記名方 式で実施された。記入もれのあった者や，後述する対処 方略項目に回答しなかった者を除き，402名（男子190 名，女子212名）を分析対象とした。

これらの被験者の一部に対して，1986年10月下旬， 1987年 1 月下旬の 2 回にわたって, 追跡調査を実施し た。 3 時点での調査すべてに回答した者 132 名（男子58 名，女子74名）を分析対象とし，これらを追跡サンプル と呼ぶ。また，3時点それぞれを Time 1, Time 2, Time 3 と略記する。

\section{質問紙の構成}

質問紙は，回答者の基本的属性に加え，孤独感尺度， 対処方略項目，および自尊心尺度から構成されている。 追跡調査では, Time 3 で社会的望ましさ尺度が加えら れた。

1）孤独感尺度： Russell et al.（1980）によって作 成された改訂 UCLA 孤独感尺度の 20 項目を次の 2 基準 で評定させた。まず，“ここ 2 週間の状態”という基準で 20項目それぞれについて “たびたび感じる゙から“けっ して感じない”の 4 点尺度で評定させた。次に, “ここ 1 年間の状態" という基準で同様に評定させた。前者を短 期的孤独感尺度，後者を長期的孤独感尺度と呼ぶ。この 評定順は, 清水・今栄（1981）の状態一特性不安尺度の 研究にならった。なお, 孤独感が強いほど高得点になる ようにした（1点から 4 点）。

2) 対処方略項目：孤独に対する対処方略項目を収 集するために本調査と同じ大学の 1,2 年生を対象に自 由記述調査を実施した（1986年 1 月下旬実施，男子 32 名, 女子 80 名)。この調查から得られた自由記述回答を整 理し, 先行研究で用いられている項目を加え, 合計71項 目の対処方略項目を作成した。

これらの項目それぞれに対して，被験者自身が孤独を 
感じたときにとる行動にあてはまる程度を, “かなりあて はまる ( 5 点)" から “ほとんどあてはまらない (1 点)" の 5 点尺度で評定させた。なお, 孤独をまったく感じた ことがない者（3名）には回答を求めなかった。

3）自尊心尺度：Rosenberg（1979）の自尊心尺度 （10項目）を用い，各項目が自分自身にあてはまる程度 を“かなりあてはまる”から“ほとんどあてはまらない” の 5 点尺度で評定させた。自尊心が高いほど高得点にな るようにした (1 点から 5 点)。

4）社会的望ましさ尺度：Crowne \& Marlowe （1964）によって作成された社会的望ましさ尺度（33項 目）を邦訳し，それぞれの項目が自分自身の行動や気持 ちにあてはまる程度を“かなりあてはまる”から“ほと んどあてはまらない”の 5 点尺度で評定させた。得点は 社会的承認欲求が強いほど高得点になるようにした（1 点から 5 点)。

なお，本調查および追跡調査の Time 2 では上述の 1)，2，3）の順に評定させ, 追跡調査の Time 3 では上 述の4）をこれらに続けた。項目の順序効果をなくすため に項目順序の異なるタイプの尺度を用いた。1)，2，3） の尺度では 4 タイプ, 4) の尺度では 3 タイプである。た だし, 孤独感尺度では 2 基準の評定で夕イプが異なるよ うにした。

\section{結果}

\section{孤独感と自尊心}

1. 孤独感尺度および自尊心尺度の検討

402名を対象として, 両孤独感尺度および自尊心尺度 の内的整合性を検討した。

1）孤独感尺度：2つの孤独感尺度それぞれで $\mathrm{GP}$ 分析を行ったところ,すべての項目において $0.1 \%$ 水準 で有意差が認められ，2つの尺度での 20 項目はいずれも 高い弁別性をもつといえた。20項目での $\alpha$ 係数も短期的 孤独感尺度で.878(男子.878, 女子.876), 長期的孤独感 尺度で.898（男子.894，女子.903）と十分に高かった。 したがって，2つの基準で評定させた孤独感尺度それぞ れでの 20 項目の合計得点を, 短期的孤独感得点および長 期的孤独感得点とした。なお, 両尺度得点の間には, 男 女ともに, 高い正の相関が得られた（男子.797, 女 子.743，いずれも $p<.001) 。$

2) 自尊心尺度：GP 分析の結果, すべての項目で $0.1 \%$ 水準で有意差が認められた。10項目での $\alpha$ 係数 も.823（男子.809, 女子.834）と十分に高かったので, 10項目の合計得点を自尊心得点とした。

2 . 尺度得点
まず， 2 つの孤独感得点の性差を検討した。短期的孤 独感については男子のほうが女子よりも有意に高い傾向 が見出されたが（男子： $\bar{X}=39.73, S D=8.78$ ；女子： $\left.\bar{X}=37.53, S D=8.17 ; t_{400)}=2.59, p<.01\right)$, 長期的孤 独感に性差は認められなかった（男子: $\bar{X}=38.35$, $S D=8.71$; 女子 $: \bar{X}=37.48, S D=8.96 ; t_{(400)}=$ $0.99, n s$.$) 。また, 男子では, 長期的孤独感よりも短期的$ 孤独感のほうが高かったが（対応のある $t$ 検定, $t_{189)}=$ $3.41, p<.001)$, 女子では差がなかった $\left(t_{211}=0.12\right.$, ns.)。

自尊心得点については, 男子のほうが女子よりも有意 に高かった（男子: $\bar{X}=31.75, S D=6.89$; 女子 : $\bar{X}=$ $\left.30.15, S D=6.84 ; t_{400)}=2.34, p<.05\right)$ 。

次に, 孤独感と自尊心との相関をみたところ, 男女と もに，短期的および長期的孤独感いずれにおいても自尊 心との間に有意な負の相関があった（男子：短期的孤独 感 -.425 , 長期的孤独感 -.360 ; 女子:それぞれ, $-.410,-.396$, いずれも, $p<.001)$ 。

3. 孤独感扔よび自尊心の安定性

追跡サンプルを対象として，a） 3 時点における各項 目の一貫性，b）各尺度ごとの 3 時点間の得点の一貫性 について検討した。なお,一貫性の指標として $\alpha$ 係数を 用いた。

a ）については，女子の長期的孤独感尺度および自尊 心尺度を除き, 測定の反復による $\alpha$ 係数の高まりがみら れた(.039〜.054の増加)。しかし, 3 尺度の平均値につ いて, 男女別に測定時点を被験者内要因とする一元分散 分析を行ったが, いずれでも有意な平均值変化は認めら れなかった（男子： $F_{(2,114)}=0.28 \sim 2.05$;女子： $F_{(2,146)}=0.12 \sim 2.39$, いずれも ns.)。したがって, “適応 のよい方向への変動”（速水，1976）とはいえない。b) については，いずれの尺度においても男女とも 3 時点間 の得点の一貫性は十分に高かった（.856〜.928)。

4. 孤独感と社会的承認欲求

追跡サンプルに対して社会的望ましさ尺度を実施した が (Time 3), 孤独感尺度評定に与える社会的承認欲求 の影響について検討する。

1）社会的望ましさ尺度の検討： GP 分析の結果， 5 項目 (原項目番号 : 7, 18, 20,25,32) が除かれ, 残りの 28 項目についての GP 分析では, すべての項目で $5 \%$ 水準 で有意差が認められた。また, 28 項目での $\alpha$ 係数 は.796（男子.794，女子.794）と十分に高かったので, 28項目の合計得点を社会的望ましさ得点とした。この得 点に性差は認められなかった（男子: $\bar{X}=73.93, S D=$ 10.67 ; 女子 : $\bar{X}=77.65, S D=10.80 ; t_{130)}=-1.97$, 
ns.)。

2) 孤独感と社会的承認欲求： Time 3 での 2 つの 孤独感得点と社会的望ましさ得点との相関をみたが, 短 期的および長期的孤独感のいずれにおいても男女ともに 有意な相関はなかった (男子 : 短期的孤独感- .104 , 長期 的孤独感 -.035 ; 女子:それぞれ, .034, -.131, すべ $\tau, n s$.$) 。さらに, 短期的孤独感と長期的孤独感の得点差$ と社会的望ましさ得点との間にも有意な相関はなかった

(男子：-.148; 女子：.224, いずれもns.)。Time 1 お よび 2 で測定した孤独感との相関も求めたが，いずれも 有意でなかった。したがって, 社会的承認欲求の強い者 が短期的孤独感よりも長期的孤独感の表明を抑制するこ ともないといえる。

\section{対処方略}

\section{1. 対処方略項目の因子分析}

孤独感の対処方略の構造を明らかにするために因子分 析を行った。71項目を対象として因子分析（主因子法） による予備的検討を行ったところ, 因子構造に性差が認 められた。さらに, 項目の平均評定値にも性差が多く検
出された(48項目)。したがって, 次の手順で男女別に因 子分析を行った。まず, 平均評定值が 2 点を下回る項目 および 4 点を上回る項目を除外した（基準： $p<.05$; 男 子： 2 点以下 15 項目 ; 女子 2 点以下 10 項目, 4 点以上 1 項目)。残りの項目 (男子56項目, 女子60項目) を対象に 因子分析（主因子法, 直交回転）を行ったが, その際, 固有值の変化の推移拉よび各因子次元の解釈可能性を考 慮して抽出因子数を決めた。その結果, 男子では 7 因子 解(固有值 $\geqq 1.83$, 説明率 $47.2 \%$ ), 女子では 6 因子解を (固有值 $\geqq 2.20$, 説明率 $41.0 \%$ ), それぞれ採用した。次 に，a）直交回転後の因子負荷量の絶対值が.400以上で あること，b）重複して a ）のことが複数の因子次元に 生じていないこと，を基準として各因子次元の代表項目 を選択した。これらの代表項目の単純合計得点を各対処 方略得点としたが，それぞれで内的整合性を $\alpha$ 係数に よって確認した。これらの結果を Table 1，2 に示す。斜 交解も検討したが，ほとんど同じ結果をもたらした。

1）男子：第 I 因子および第 V因子は, 既存の友だちと の関係を利用した達成水準の変化に関する方略である。

Table 1 男子 $(N=190)$ における対処方略の基本的構造

一 因子分析（主因子法，直交回転）の結果 -

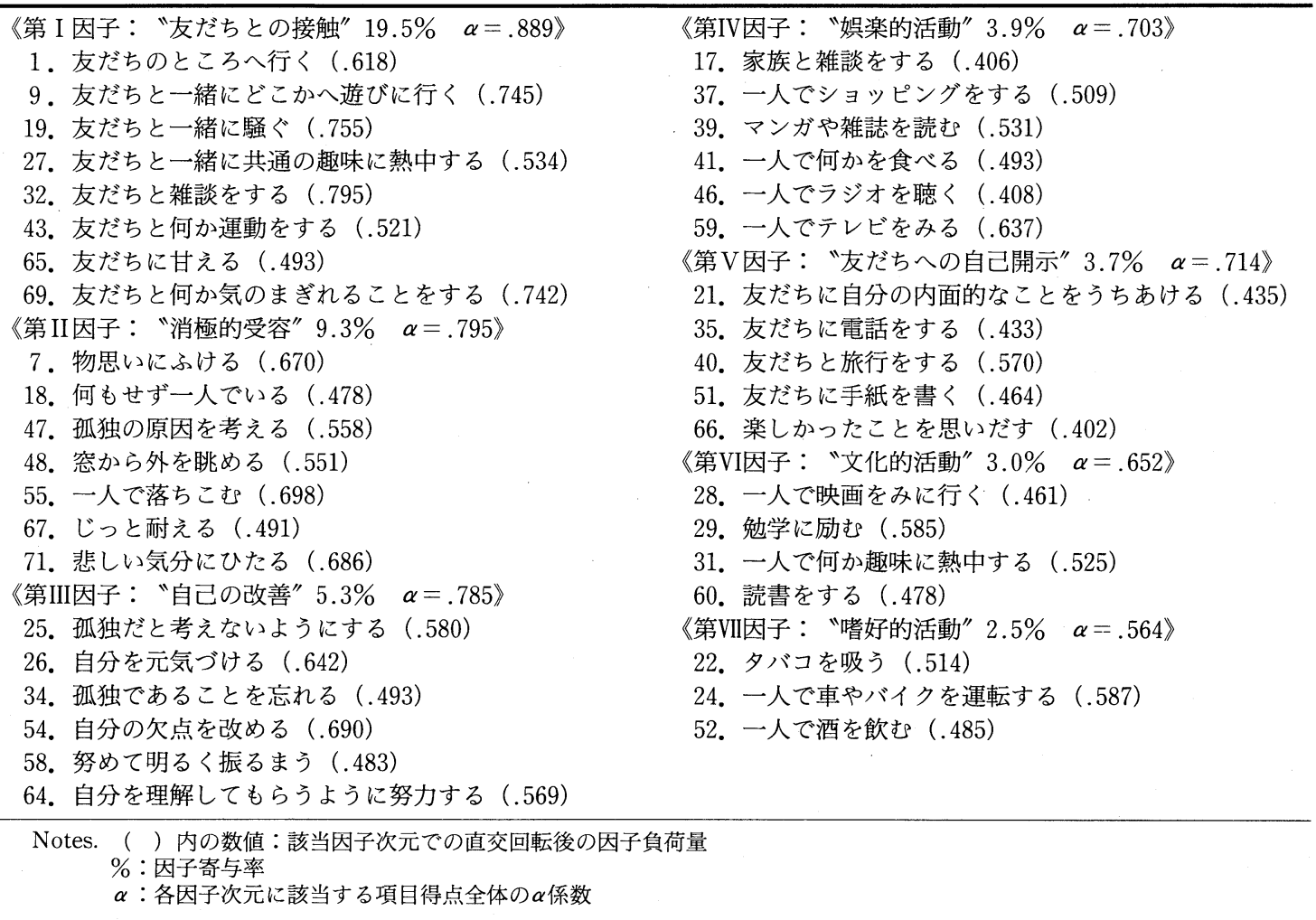


Table 2 女子 $(N=212)$ における対処方略の基本的構造

一 因子分析（主因子法，直交回転）の結果 -
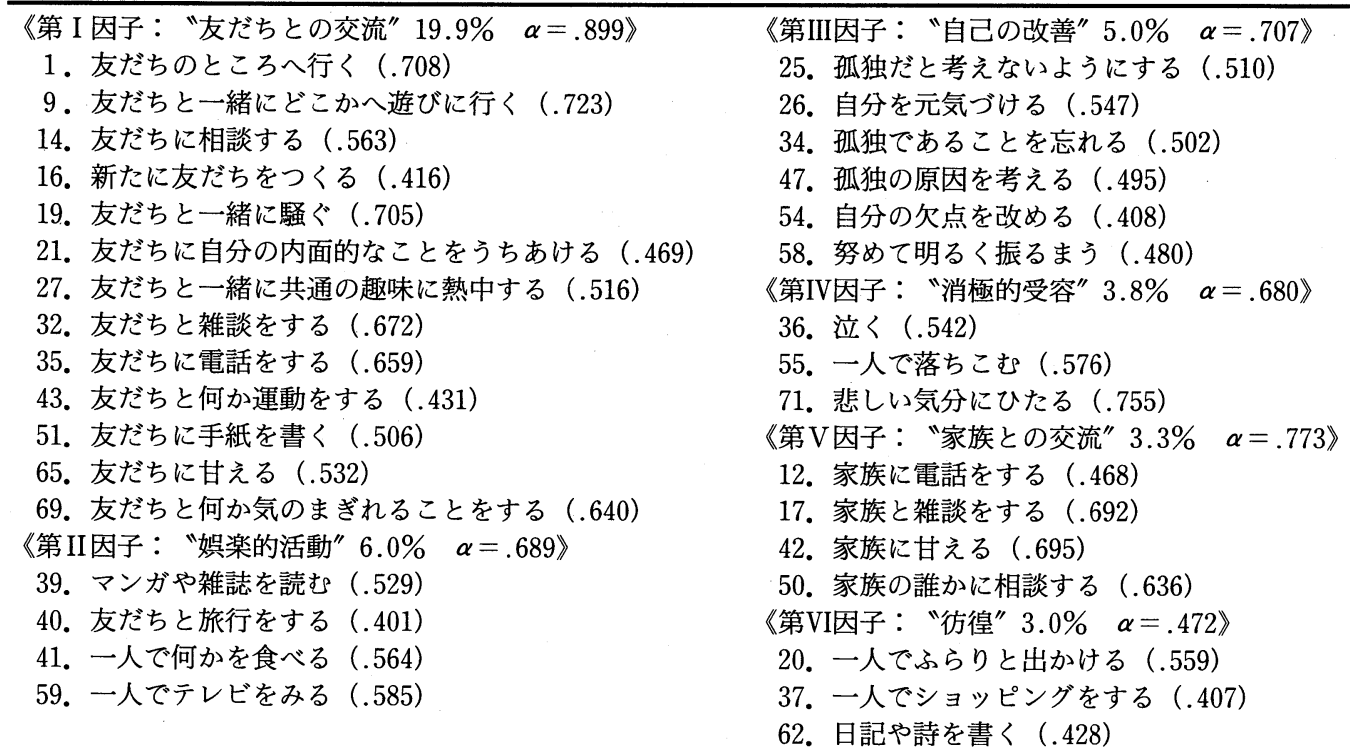
Notes. （）内の数值：該当因子次元での直交回転後の因子負荷量 $\%$ : 因子寄与率 $\alpha$ : 各因子次元に該当する項目得点全体の $\alpha$ 係数

これら 2 因子は接触の親密さで区別され,第 I 因子は“友 だちとの接触” 因子，第V因子は “友だちへの自己開示” 因子と命名した。第II因子は, 孤独に対する無抵抗を示 しているので “消極的受容” 因子と命名した。孤独の否 定と自己の状態の積極的改善を示す第III因子は, “自己の 改善”因子と命名した。残りの 3 因子はいずれも，注意 を他の対象にそらすことによって孤独感を解消する方略 といえる。活動の性質の違いを考慮して, 第IV因子は“娛 楽的活動”因子，第VI因子は “文化的活動” 因子，およ び第VII因子は “嗜好的活動” 因子とそれぞれ命名した。 これらの対処方略得点の相互相関は-.106から.538で あった。

2）女子：第 I 因子および第V因子は,友だちあるいは 家族という既存の対人関係を利用した達成水準の変化に 関する方略であり，それぞれ，“友だちとの交流”因子， “家族との交流” 因子と命名した。第II因子は，男子の 第IV因子と類似しており，“娛楽的活動”因子と命名し た。第III因子および第IV因子は，それぞれ男子の第III因 子および第II因子に対応しており，“自己の改善”因子， “消極的受容” 因子と命名した。第VI因子は, 行動上, 心理上の彷彺を意味しているので “彷彺” 因子と命名し た。これらの対処方略得点の相互相関は.011から.478で
あった。

\section{2. 対処方略因子の安定性}

追跡調査を利用して, 先の分析で得られた対処方略因 子の安定性を，一貫性の指標として $\alpha$ 係数を用い，a） 3 時点における各対処方略項目の一貫性, b ) 各対処方 略ごとの 3 時点間の得点の一貫性, という点から検討し た。

a)については, 男子では, 友だちとの接触, 消極的 受容, 自己の改善, および友だちへの自己開示が, 女子 では, 友だちとの交流, 自己の改善, 消極的受容, およ び家族との交流が，それぞれ，3時点通して該当項目の 一貫性が高かった(.673〜.905)。b）については，いず れの方略でも男女ともに 3 時点間の一貫性は高かった

\section{(.752〜.921)。}

3. 対処方略項目平均值における性差

男女で異なる対処方略因子が得られたので, 各対処方 略のとりやすさにおける性差を対処方略因子が構成され る項目の平均值を比較することによって間接的に検討す る $(t$ 検定, $p<.05)$ 。

男子によってとられる対処方略項目は, 友だちとの接 触に含まれる 4 項目 (項目 $1,9,27,43$ ), 文化的活動に含 まれる 1 項目 (項目28), 嗜好的活動に含まれる 3 項目(項 
目22,24,52)であった。女子によってとられる対処方略 項目は，友だちとの交流に含まれ，とくに自己開示に該 当する 5 項目 (項目 $14,21,35,51,65$ ), 娛楽的活動に含ま れる 1 項目 (項目41), 自己の改善に含まれる 4 項目 (項 目 $26,47,54,58$ ), 消極的受容に含まれる 3 項目 (項目 $36,55,71$ ), 家族との交流に含まれる 4 項目 (項目 12 , $17,42,50$ ), 彷徨に含まれる 2 項目 (項目 37,62 ) であっ た。

\section{孤独感と対処方略}

\section{1. 重回帰分析}

短期的および長期的孤独感に有意に影響をおよほして いる対処方略を明らかにするために，長期的孤独感を従 属変数, 各対処方略を説明変数とする重回帰分析, なら びに短期的孤独感を従属変数, 長期的孤独感および各対 処方略を説明変数とする重回帰分析を行った。この結果 を, ピアソン相関とともに, Table 3 に示す。

1）男子：長期的孤独感の有意な規定因として認めら れた方略は, 友だちとの接触, 友だちへの自己開示, 消 極的受容であった。前 2 者は孤独感を抑制, 後者は促進 するといえる。短期的孤独感については, 長期的孤独感 が強く影響しているが，友だちとの接触の抑制的影響も 認められる。

Table 3 短期的および長期的孤独感と対処方略 一重回㷌分析（一括投入法）の結果 -

\begin{tabular}{|c|c|c|}
\hline & \multicolumn{2}{|c|}{ 標準偏回帰係数（ピアソン相関） } \\
\hline & 長期的孤独感 & 短期的孤独感 \\
\hline \multicolumn{3}{|l|}{ 【 男子 】 } \\
\hline 第 I 因子 & $-.247 b(-.354 a)$ & $-.143 c(-.391 a)$ \\
\hline 第II因子 & $.180 c(.217 b)$ & $.083 \cdot(.260 a)$ \\
\hline 第III因子 & $-.049 \quad(-.166 c)$ & $-.069 \quad(-.208 b)$ \\
\hline 第IV因子 & $.109(-.022)$ & $.049(-.003)$ \\
\hline 第V因子 & $-.238 b(-.294 a)$ & $.082(-.216 b)$ \\
\hline 第VI因子 & $.144 \quad(.098)$ & $.002(.085)$ \\
\hline 第VII因子 & $-.073(-.111)$ & $-.074(-.156 \mathrm{~b})$ \\
\hline 長期的孤独感 & & $.734 a(.797 a)$ \\
\hline$R^{2}$ & $.224 a$ & $.671 \mathrm{a}$ \\
\hline \multicolumn{3}{|l|}{ 【女子 】 } \\
\hline 第 I 因子 & $-.397 a(-.375 a)$ & $-.093(-.334 a)$ \\
\hline 第II因子 & $.016 \quad(-.158 c)$ & $.016(-.119)$ \\
\hline 第III因子 & $.002 \quad(-.166 c)$ & $-.026(-.167 c)$ \\
\hline 第IV因子 & $.152 c(.145 c)$ & $-.017(.087)$ \\
\hline 第V因子 & $.023 \quad(-.124)$ & $.059 \quad(-.066)$ \\
\hline 第VI因子 & $.005 \quad(-.068)$ & $.056(-.010)$ \\
\hline 長期的孤独感 & & $.719 a(.743 a)$ \\
\hline$R^{2}$ & $.165 a$ & $.562 a$ \\
\hline
\end{tabular}

Notes. $\mathrm{a}: p<.001 ; \mathrm{b}: p<.01 ; \mathrm{c}: p<.05$
2）女子：長期的孤独感では, 友だちとの交流の抑制的 影響, 消極的受容の促進的影響が認められた。短期的孤 独感については, 長期的孤独感の強い影響のみがあった。 2. 孤独感の慢性化と対処方略

1）被験者の選別：2つの孤独感得点に基づき，a）孤 独水準が慢性的に同水準にある者, およびb）慢性的状 態に比べ，一過的に孤独感が変化している者の区別を試 みた。Gerson \& Perlman（1979）にしたがって, 短期 的および長期的孤独感のそれぞれの得点分布の上位, 下 位33\%を基準に被験者を 9 分割した(男子一短期的孤独 感: 22 34点, 35〜 43点, $44 \sim 66$ 点; 長期的孤独感: 22〜34点, 35〜 42点, 43〜 70点/女子一短期的孤独感: 21 33点, 34〜 40点, $41 \sim 68$ 点; 長期的孤独感： $23 \sim 32$ 点, 33〜 40点, $41 \sim 77$ 点)。しかし, 両得点間の高い相関 を反映して，男女いずれにおいても先のａ）に該当する 者が大半であった。また, 孤独感の一過的変化を示した 者の対処方略の特徴が探索的分析で検出されなかったの で, 以下の分析は孤独水準が慢性的に同水準にある者に 限定した。両得点ともに, 上位水準にある者を $\mathrm{Hi}$ 群, 中 位水準にある者を Mo 群, 下位水準にある者を Lo 群と した(男子：Hi 群50名, Mo 群37名, Lo 群48名；女子： それぞれ52名, 41名, 50名)。

男女ともに，3群間に短期的および長期的孤独感いず れでも明確な差があった（男子一短期的孤独感： $F_{(2,132)}=302.17$; 長期的孤独感: $F_{(2,132)}=289.30 /$ 女子 一それぞれ, $F_{(2,140)}=298.65, F_{(2,140)}=246.84$, いずれ も $p<.001)$ 。さらに, 選別の妥当性を検討するために, 追跡サンプルでこれらの 3 群に選別された者を対象とし て(男子：Hi 群11名, Mo 群11名, Lo 群14名；女子：そ れぞれ, 18名, 15名, 22名), 孤独水準(3)×孤独感の評定 基準(2)×測定時点(3)の混合要因の分散分析を男女別に 行った(後 2 要因は被験者内要因)。男子では, 孤独水準 の主効果 $\left(F_{(2,33)}=41.23, p<.001\right)$ と孤独水準 $\times$ 測定時 点の交互作用 $\left(F_{(4,64)}=3.33, p<.05\right)$ が有意で, $\mathrm{Hi}$ 群, Mo 群, Lo 群の間の差が, 測定の反復によって少し 縮まるが 3 群間の差が保たれる傾向を示した。女子では, 孤独水準の主効果 $\left(F_{(2,52)}=76.47, p<.001\right)$ のみが有意 であった。したがって, 男女ともに, 孤独水準の 3 群へ の選別は時間を超えた妥当性があるといえよう。

2) 判別分析：各対処方略を説明変数とし, Hi 群, Mo 群, および Lo 群を判別対象とする判別分析（一括投入 法）を行った。Table 4 に結果を示す。男女ともに, Hi 群と Lo 群とを判別する関数のみが有意であり（男子： $F_{(14,252)}=2.92, p<.001$; 女子 : $F_{(12,270)}=2.28$, $p<.01)$, 第 2 の関数は有意でなかった。男子では, $\mathrm{Hi}$ 群 
Table 4 慢性的な孤独感の水準と対処方略 一判別分析 (一括投入法) の結果 -

\begin{tabular}{lcc}
\hline & \multicolumn{2}{c}{ 標準化判別係数 } \\
& 男子 & 女 子 \\
\hline 第 I 因子 & $.454\langle\mathrm{a}\rangle$ & $1.046 \mathrm{a}\langle\mathrm{a}\rangle$ \\
第II因子 & $-.587 \mathrm{c}\langle\mathrm{b}\rangle$ & -.011 \\
第III因子 & .150 & -.013 \\
第IV因子 & -.313 & -.379 \\
第V因子 & $.527 \mathrm{c}\langle\mathrm{b}\rangle$ & -.358 \\
第VI因子 & -.209 & -.107 \\
第VII因子 & .322 & - \\
重心 Lo群 & $.661(35 / 48)$ & $.444(36 / 50)$ \\
Mo群 & $.034(0 / 37)$ & $.146(0 / 41)$ \\
Hi群 & $-.659(40 / 50)$ & $-.542(33 / 52)$ \\
\hline
\end{tabular}

Notes. ( ) 内: 分類成功ケース数/所属ケース数 〈>内: 一元分散分析の $F$ 值の有意性 $\mathrm{a}: p<.001 ; \mathrm{b}: p<.01 ; \mathrm{c}: p<.05$

の対処方略として消極的受容, Lo 群の対処方略として 友だちへの自己開示を挙げることができる。女子では, 友だちとの交流のみが有意であり, Lo 群の対処方略と いえる。男子では，一元分散分析で友だちとの接触方略 も有意であった。

\section{考察}

\section{孤独感と自尊心}

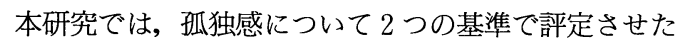
が, 短期的孤独感と長期的孤独感との間にはかなり高い 正の相関がみられた。また，長期的孤独感よりも短期的 孤独感のほうが変動が大きいことが予測されるが，追跡 調査では $2 つ の$ 孤独感得点の測定時点間の一貫性はいず れもかなり高かった。特性一孤独感と状態一孤独感との 区別を試みた Shaver et al. (1985) の研究では, 夏から 翌年の春にかけて 4 回測定されたが，2つの孤独感の間 の相関はあまり高くなく $(.40 \sim .60)$, 特性一孤独感での 測定時点間の相関は (.77〜 .83), 状態一孤独感での相関 よりも高かった(.29〜.64)。つまり, Shaver et al.(1985) の被験者は孤独感の評定基準に敏感に反応しているが, 本研究の被験者は 2 つ基準にあまり影響されない。わ が国の先行研究での 2 つの測定時点間の相関が高いこと を考えると（工藤・西川，1983：6ヶ月間隔, .546; 諸 井, 1986：3 ケ月間隔, .766), 日本の大学生の孤独感は 個体特性成分の占める割合が大きいのかもしれない。し かし, 従来の研究で指摘されている性差が長期的孤独感 よりも短期的孤独感でみられたことから，本研究で試み た孤独感の区別は意味がある。
短期的孤独感に抢ける性差は, Borys \& Perlman （1985）が指摘するように男子が慢性的孤独に陥りやす いが, 性役割上, 長期的な孤独状態の表明が抑制される ことを示しているのかもしれない。しかし，孤独感と社 会的承認欲求との間に弱いが有意な相関を認めた先行研 究と異なり (Russell et al., 1980 ; 工藤・西川, 1983； 諸井, 1986), 有意な関係が認められなかったので,この 解釈は妥当とはいえない。むしろ, 長期的にみた場合に は孤独感の高さに性差はないが, 男子のほうが一過的に 状況の影響を被りやすいために短期的孤独感が高いと解 釈できよう。

ところで, 評定基準にかかわらず孤独感と自尊心との 間に男女ともに有意な負の相関があり,さらに男子のほ うが女子よりも自尊心が高かった。したがって, 孤独感 と自尊心に関して諸井（1985，1987）が見出した矛盾的 傾向は短期的孤独感に限定される。Shaver et al.(1985) が指摘するように, 通常用いられる “普通の状態”とい う評定基準は, 被験者の孤独状態によってその時間的範 囲が設定されると考えられる。先行研究で見出された男 子の高い孤独感は, 孤独感の評定が短期的基準によった ためと解される。後述するように, 男子の短期的孤独感 は長期的孤独感の強い影響に加え, 友だちとの接触方略 によっても規定されているが，これは男子が一過的に状 況の影響を被りやすいという考えと一致する。

いずれにせよ, 本研究で試みた孤独感の 2 成分の区別 は今後もさまざまな方法で検討すべきであろう。

\section{孤独感と対処方略}

本研究では, 男子では 7 , 女子では 6 つの対処方略 因子が得られた。男女に共通した対処方略は, 消極的受 容, 自己の改善, 娛楽的活動であった。男女それぞれに 固有の因子もあった。社会的関係に関する方略として， 男子では, 親密さの水準に対応して, 友だちとの接触, 友だちへの自己開示の方略が分離して得られ，女子では， 対象の違いによって, 友だちとの交流, 家族との交流の 方略が得られた。その他, 男子では文化的活動, 嗜好的 活動, 女子では, 彷得という対処方略が認められたが, 嗜好的活動や彷彺は性役割行動を反映した方略といえよ う。

対処方略のとりやすさにおける性差を項目水準で間接 的に検討したところ, 次の特徵的傾向が得られた。孤独 に陥ったときに, 男子は主として友だちとの接触を高め るのに対し，女子は，消極的受容方略に依存するものの， 友だちへの自己開示や家族との交流を高め, 自己の改善 にも努める。女子の孤独感の対処が多様で積極的である ことは孤独感の低さと対応している。 
次に，これらの対処方略を Peplau \& Perlman (1979) の対処方略図式に対応させる。友だちとの接触，友だち への自己開示，友だちとの交流，および家族との交流は， 達成水準の変化に関する方略であり, 自己の改善も達成 水準の変化を促すという点でこれに含められる。消極的 受容方略は, 時間的経過による願望水準の変化といえよ う。他の方略は, 願望水準の変化と達成, 願望の両水準 のくいちがいに関する認知的歪曲のいずれとも解釈でき る方略である。娱楽的活動, 文化的活動は, 単独で楽し める課題状況の選択という点で前者, 代理的対象による 対人接触欲求の充足という点では後者の方略といえる。 また, 暂好的活動, 行得は, 時間的経過による願望水準 の変化とも解されるし, 孤独感がもたらすネガティブな 影響を緩和する行動という点では, 達成, 願望の両水準 のくいちがいに関する認知的歪曲の方略といえる。

ストレス事態における対処方略に関する研究では，ス トレスの源泉の回避・除去を目標とする問題中心的対処 と, ストレス事態と結びついたネガティブな情動の低 減・除去の企てである情動中心的対処とが区別されてい る (Folkman \& Lazarus, 1980)。本研究で得られた対 処方略も, 孤独感の原因である社会的関係の不全を改善 する問題中心的対処（男子：第 I, III, V因子 ; 女子： 第 I, III, V因子）と，孤独の不快経験を一時的に癒す 情動中心的対処（男子：第II, IV, VI, VII因子；女子： 第II，IV，VI因子）とに区別できょう。

本研究のみならず他の研究結果をみても, Peplau \& Perlman（1979）の対処方略図式に従った当該の対処方 略の位置づけは, 願望水準の変化方略と, 達成, 願望の 両水準のくいちがいに関する認知的方略との区別の点で, 曖昧になりがちである。したがって, 今後は, 彼らの図 式に限定されずに, ストレス研究における対処方略の基 本的構造に関する研究知見とも積極的に関連づけて, 孤 独感の対処方略の基本的構造を検討する必要があろう。

次に, 孤独感と対処方略との関係について検討する。 重回帰分析の結果は, 男女ともに, 友だちとの関係に関 する方略は孤独感の低減に有効であるが，消極的受容方 略はむしろ孤独感の長期化をもたらすことを示している。 短期的孤独感については，男女ともに長期的孤独感に よって強く規定されるが，男子では友だちとの接触方略 も有効であった。孤独感を有意に規定していると認めら れた対処方略は，追跡調查において測定時点での高い内 的一貫性を示しているので，安定した対処方略であると いえる。

ところで, 先述したストレス研究においては, 問題中 心的対処と情動中心的対処が区別されているが，前者は
そのストレス事態が統制可能と認知されたときに，後者 はその事態を受容するしかないと認知したときに，それ ぞれ生起しやすい (Folkman \& Lazarus, 1980 ; Folkman et al., 1986)。したがって, 本研究の結果について も，長期的に孤独状態にある者がその事態を統制不可能 であると認知し，情動中心的対処である消極的受容方略 に依存するのに対し，長期的には孤独状態にない者が孤 独状態を統制可能であると認知し，問題中心的対処をと ると，解釈できる。事態の統制可能性の認知を媒介させ るこの解釈は, 孤独感の原因㷌属の問題と関連する。 $\mathrm{Pe}$ plau \& Perlman（1979）は，孤独状態を内的で不安定な 原因に帰属すると積極的対処が喚起されるが，安定した 原因への帰属は対処を消極的にすることを示唆している。 また, 孤独感の原因が内在性抢よび安定性の 2 次元上に 位置づけられ，統制可能性次元を必要としないことが見 出されている (Michela et al., 1982)。今後, ストレス 研究で得られた知見の孤独感と対処方略との関係への適 用を含め, 孤独感と対処方略との関係に原因帰属の機制 を媒介させた検討が必要といえる。

次に，孤独感の慢性的水準と対処方略との関係を検討 した判別分析の結果について述べる。男子では，友だち への自己開示方略は孤独感の慢性化を妨げ，消極的受容 方略が慢性化を促進する。しかし，女子では，友だちと の交流方略のみが慢性化を妨げる方略であった。孤独感 と社会的相互作用の関係を検討したWheeler et al.

（1983）の研究では，女性パートナーとでは相互作用時 間, 男性パートナーとでは相互作用の意義深さがそれぞ れ孤独感と負の関係にあった。したがって，項目に明確 に表現されていないが，本研究での友だちとの関係に関 する対処方略が同性関係に関わるものとすれば，男子で は単なる接触よりもむしろ親密な交流のほうが孤独感の 抑制に効果的であることは, Wheeler et al. (1983) の 知見と一致することになる。また，友だちへの自己開示 や友だちとの交流の方略は行動的方略といえ，消極的受 容方略は認知的方略といえる。男子では両夕イプの方略 が孤独感の慢性的水準に関係しているのに，女子では行 動的方略の関連のみがあった。男子の孤独感は, 自己内 部の考えや感情への注意傾向である私的自己意識や，自 己を社会的対象として意識する傾向である公的自己意識 との関わりを示すのに，女子ではそのような関係が認め られない(諸井，1985，1987)。この孤独感と自己意識と の関係における性差を含めて考えると, 男子の孤独感が 複雑な認知的機制を伴っているのに，女子の孤独感は社 会的関係の状態を直接的に反映しているといえよう。

本研究では, 孤独感が一過的に変化している者に特徵 
的な対処方略を認めることができなかった。これは, 出 現頻度が少数であったことに加え, 孤独感の一過的変化 を引き起こす状況の性質によって用いられる対処方略が 異なるためかもしれない。このことも含め, 孤独感と対 処方略との関連についてさらに検討する必要があろう。

\section{要 約}

本研究の主目的は, 孤独感の対処方略の基本的構造を 明らかにし, 孤独感と対処方略との関連を検討すること であった。また，短期的孤独感と長期的孤独感との区別 も試みた。男女大学生 $(N=402)$ を対象として, “ここ 2 週間の状態", “ここ 1 年間の状態”という 2 つ基準で 評定させる UCLA 孤独感尺度, 対処方略項目質問紙, 自 尊心尺度を実施した。

主要な結果は以下の通りである。

1）短期的孤独感と長期的孤独感との間には高い正の 相関があった。しかし，男子の短期的孤独感は女子より も高かった。

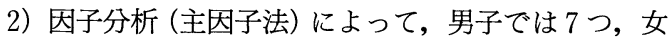
子では 6 つの対処方略因子が得られた。

3）重回帰分析によると,友だちとの関係を利用した対 処方略は長期的孤独感の低減に有効であるが，消極的受 容方略はむしろ孤独感の長期化をもたらしている。

4） 2 つの孤独感評定を利用して, 孤独感の慢性的水準 に応じた 3 群を選別し，判別分析を行った。男女ともに， 友だちとの関係を利用した方略は孤独感の慢性化を抑制 するが，男子では消極的受容方略が慢性化を促進してい た。

\section{引用 文 献}

Bèck, A. T., \& Young, J.E. 1978 College blues. Psychology Today, September,80-92.

Borys, S., \& Perlman,D. 1985 Gender differences in loneliness. Personality and Social Psychology Bulletin, 11, 63-74.

Crowne, D. P., \& Marlowe, D. 1964 The approval motive: Studies in the evaluative dependence. New York: Wiley.

Cutrona, C. E. 1982 Transition to college: Loneliness and the process of social adjustment. In L. A. Peplau \& D. Perlman(Eds.), Loneliness : A sourcebook of current theory, research and therapy. New York: John Wiley \& Sons. Pp. 291-309.

Folkman, S., \& Lazarus, R. S. 1980 An analysis of coping in a middle-aged community sample. Journal of Health and Social Behavior, 21, 219 -239 .

Folkman, S., Lazarus, R. S., Dunkel-Schetter, C., DeLongis, A., \& Gruen, R. J. 1986 Dynamics of a stressful encounter: Cognitive appraisal, coping, and encounter outcomes. Journal of Personality and Social Psychology, 50, 992-1003.

Fridhandler, B. M. 1986 Conceptual note on state, trait, and the state-trait distinction. Journal of Personality and Social Psychology, 50, 169 -174 .

Gerson, A. C., \& Perlman, D. 1979 Loneliness and expressive communication. Journal of Abnormal Psychology, 88, 258-261.

速水敏彦 1976 質問紙性格検查の再検查効果 教育 心理学研究, 24, 57-61.

広沢俊宗 1985 孤独の原因，感情反応，および対処行 動に関する研究（I） 関西学院大学社会学部紀 要, 51, 157-168.

広沢俊宗 1986 孤独の原因，感情反応，および対処行 動に関する研究（II） 関西学院大学社会学部紀 要, 53, 127-168.

工藤 力 1986 思春期の孤独感に関する研究 心理 学研究, 57, 293-299.

工藤 力・熊取谷由季央・西川正之 1986 孤独感に関 する研究 (III) 一孤独感に対する対処行動の解明 一大阪教育大学教育研究所報, 22, 65-72.

工藤 力・西川正之 1983 孤独感に関する研究 (I) 一孤独感尺度の信頼性・妥当性の検討一実験社 会心理学研究, 22, 99-108.

工藤 力・長田久雄・下村陽一 1984 高齢者の孤独に 関する因子分析的研究 老年社会科学，6，167 -185 .

Michela, J. L., Peplau, L. A., \& Weeks, D. G. 1982 Perceived dimensions of attributions for loneliness. Journal of Personality and Social Psy. chology, 43, 929-936.

諸井克英 1985 高校生における孤独感と自己意識 心理学研究, 56, 237-240.

諸井克英 1986 大学新入生の生活事態変化に伴う孤 独感 実験社会心理学研究，25, 115-125.

諸井克英 1987 大学生における孤独感と自己意識 実験社会心理学研究，26, 151-161.

Paloutzian, R. F., \& Ellison, C. W. 1982 Loneliness, 
spiritual well-being and the quality of life. In L. A. Peplau \& D.Perlman (Eds.), Loneliness : A sourcebook of current theory, research and therapy. New York : John Wiley \& Sons. Pp. 224-237.

Peplau, L. A., \& Perlman, D. 1979 Blueprint for a social psychological theory of loneliness. In M. Cook \& G. Wilson (Eds.), Love and attraction. Oxford : Pergamon. Pp. 101-110.

Rook, K. S., \& Peplau, L. A. 1982 Perspectives on helping the lonely. In L. A. Peplau \& D. Perlman (Eds.), Loneliness : A sourcebook of current theory, research and therapy. New York: John Wiley \& Sons. Pp. 351-378.

Rosenberg, M. 1979 Conceiving the self. New York: Basic Books.

Rubenstein, C., \& Shaver, P. 1982 The experience of loneliness. In L. A. Peplau \& D. Perlman (Eds.), Loneliness : A sourcebook of current theory, research and therapy. New York:
John Wiley \& Sons. Pp. 206-223.

Russell, D., Peplau, L. A., \& Cutrona, C. E. 1980 The revised UCLA Loneliness Scale: Concurrent and discriminant validity evidence. Journal of Personality and Social Psychology, 39, 472 -480 .

Shaver, P., Furman, W., \& Buhrmester, D. 1985 Transition to college: Network changes, social skills, and loneliness. In S.Duck \& D. Perlman (Eds.), Understanding personal relationships: An interdisciplinary approach. Newbury Park, CA : Sage. Pp. 193-219.

清水秀美・今栄国晴 1981 STATE-TRAIT ANXIETY INVENTORY の日本語版 (大学生用) の作 成 教育心理学研究, 29, 348-353.

Wheeler, L., Reis, H., \& Nezlek, J. 1983 Loneliness, social interaction, and sex roles. Journal of Personality and Social Psychology, 45, 943-953.

- 1988年 6 月 16 日 受稿, 1989年 5 月27日 受理 - 


\title{
LONELINESS AND COPING STRATEGIES IN UNIVERSITY STUDENTS
}

\author{
KATSUHide MoROI \\ Shizuoka University
}

\begin{abstract}
This study examined a ) the factor structure of coping strategies for loneliness and b) relationships among loneliness and coping strategies. Four scales were administered to undergraduate students $(N=402)$. The scales were two versions of UCLA Loneliness Scale(short-term loneliness, longterm loneliness), Coping Strategies Scale, and SelfEsteem Scale. Two versions of UCLA Loneliness Scale were completed with different criteria ("during the past two weeks" versus "during the past one year").

The results were as follows.

1) Short-term loneliness scores were higher for
\end{abstract}

males than for females. They were highly correlated with long-term loneliness scores.

2) The factor analysis of coping strategies produced seven factors for males, and six factors for females.

3) Results of the multiple regression analyses indicated that interpersonal coping strategies were effective in reducing long-term loneliness, while passive acceptance coping prolonged loneliness.

4) Based on the combined scores of short-term and long-term loneliness scores, subjects were divided into three groups of different levels of chronic loneliness. Results of discriminant analyses indicated that high-chronic-lonely group used interpersonal coping strategies less than low-chronic-lonely group.

Key words: loneliness, coping strategy, UCLA Loneliness Scale, chronic loneliness, transient loneliness. 